A big part of future regenerative medicine rests on stem cell research and we have still not seen the full impact of stem cell technology. So will we be growing new teeth in 50 years' time? Dr Ana Angelova Volponi's current research centres on finding a source of mesenchymal stem cells that are able to maintain toothforming ability and can be easily expanded in laboratory settings: 'Research focused on generating a "biotooth" has made big steps forward by using human adult gingival stem cells as one of the sources in the creation of a whole biotooth, where all anatomical parts of a tooth are present. ${ }^{4}$ Yet others, such as Professor Sloan, do not foresee growing teeth as the future for dentistry, with stem cell technology able to overcome all dental damage: 'It may be possible, but will it be clinically practicable?'

The regenerative approach to periodontology is developing rapidly, as Dr Angelova Volponi asserts: 'Often we see a combination of cell-based therapy, gene therapy and application of scaffolds to deliver cells and genes for periodontal regeneration - even 3D printed scaffolds have been shown to be useful in this area. ${ }^{5}$

Perhaps in half a century many of these treatments will be seen in the dental clinic.

1. Oxen thigh bones to make wartime brushes. Br Dent J 2014; 217: 61.

2. Khatoon B, Hill K B, Walmsley A D. Can we learn, teach and practise dentistry anywhere, anytime? Br Dent J 2013; 215: 345-347.

3. Battersby J. Is CAD/CAM the end for dental labs? BDJ Team 2014; doi:10.1038/ bdjteam.2014.63.

4. Angelova Volponi A, Kawasaki M, Sharpe P T. Adult human gingival epithelial cells as a source for whole-tooth bioengineering. J Dent Res 2013: 92: 329-334.

5. Park C H, Rios H F, Taut A D et al. Imagebased, fiber guiding scaffolds: a platform for regenerating tissue interfaces. Tissue Eng Part C Methods 2014; 20: 533-542.

BY LAURA PACEY

This is Laura's final piece for the Journal. We would like to thank her for all of her hard work and valued contributions during her time on the editorial team.

\title{
BDA FIGHTS FOR FAIR FEES AND DECENT REGULATION
}

On 17 October 2014 the British Dental Association (BDA) announced that it has initiated judicial review proceedings against the General Dental Council (GDC).

The GDC, which has faced heavy criticism from the Professional Standards Authority on the way it deals with patient complaints, has recently announced its desire to increase the professional fees paid by dentists by $64 \%$. The BDA has accused the GDC of failing to provide clear evidence of the policy or business case that have underpinned the mooted fee rise - rendering the regulator's case unlawful.

Mick Armstrong, Chair of the BDA's Principal Executive Committee, said: 'We are being asked to pay the price for our regulator's mismanagement, and we won't stand for it. We are determined to fight for fair fees and decent regulation. We have given the GDC every opportunity to demonstrate they have built a reasoned, evidenced and lawful case for this fee hike. They have chosen not to respond, and now we will leave it to the courts to decide'.

GDC plans would see dentists fees rise from $£ 576$ to $£ 945$ - the highest fee charged by any comparable healthcare regulator, and they will have no choice but to pay, as they must be registered with the GDC in order for them to practise lawfully.

\section{GDC pledges openness and honesty}

The GDC is among eight UK professional healthcare regulators to publish a joint statement, setting out their commitment to a duty of candour for healthcare professionals, and pledging to do more to put openness and honesty at the heart of healthcare.

This joint statement is a milestone in ensuring universality across all the professions. This common duty makes clear to patients what they can and should expect of those who treat them and give them confidence that, should professionals fall short of those expectations, regulators will respond accordingly.
The full statement on 'Openness and honesty - the professional duty of candour' can be read at: http://image.s4.exct.net/ lib/fe921570706d027d7d/m/1/Joi nt+statement+on+candour+13+ Oct+2014.pdf.

Dental professionals understand their ethical duty

The Dental Defence Union (DDU), in responding to the joint statement by eight UK health regulators on the importance of being open and honest with patients, said that dental professionals understand that candour is central to their relationship with their patient.

Rupert Hoppenbrouwers, Head of the DDU, said: 'While we welcome the emphasis being placed on candour by the GDC and other regulators, our experience is that dental professionals overwhelmingly understand their longstanding ethical duty to be open and honest with patients.

'They appreciate that having an open dialogue with patients is not something to be afraid of. When something goes wrong, dental professionals tell us time and again that apologising early to the patient or their family can help resolve a complaint more quickly or prevent one altogether - so it's to everybody's advantage to be open and honest from the outset'

\section{BDA-BDJ WINTER LECTURE 2014}

The BDA-BDJ Winter Lecture 2014 will be given by Dr Michele Barbour (pictured), Senior Lecturer in Dental Biomaterials at the University of Bristol, on 10 December 2014.

Dr Barbour, who is also head of the University of Bristol's Oral Nanoscience research group, focusses research on the application of nanotechnology to dental materials and, in particular, the design and synthesis of antimicrobial nanoparticles for applications in dentistry.

Taking place at the BDA offices in London, Dr Barbour will review the ever changing world of dental materials and determine exactly what benefits these 'new' materials offer, and how they differ from what came before. She will then discuss the exciting directions that dental materials will take in the future.

The Winter Lecture is sponsored by the Wrigley Oral Healthcare Programme and a festive reception will follow the lecture. One hour of verifiable continuing professional development (CPD) is available for those attending.

Tickets are complimentary for BDA members and will be allocated by a ballot which closes on 19 November. To apply, visit www.bda.org/winterlecture or email winterlecture@bda.org.

A recording of the lecture will be made available after the event for all members to view online. 